\title{
Introduction:
}

\section{The Good and Evil Within}

The dramas of Fritz Hochwälder (28.5.1911 - 20.10.1986) have, somewhat inexplicably, been given little attention by literary critics, despite the fact that the Austrian dramatist was, with Max Frisch and Friedrich Dürrenmatt, at the forefront of German language drama in the immediate post-war period and right through the mid-1950s. Even as late as 1967 Hochwälder could, with some justification, be referred to as the most performed post-war Austrian dramatist ${ }^{1}$. This study aims to rectify this oversight, by providing the first complete overview of his dramatic aeuvre, both published and unpublished plays, and by examining the importance of the theme of conscience and personal responsibility in Hochwälder's work.

Several contributory factors to Hochwälder's relative obscurity ${ }^{2}$ can be identified. Firstly, he remained for his entire writing career something of an outsider. Trained and employed as a Tapezierer, it was only when forced into exile from Vienna by the Anschlu $\beta$ in 1938, an event that would lead to the death of his Jewish parents, that writing, hitherto merely a hobby, became a career ${ }^{3}$. He was to spend the rest of his life in Zurich, rather than returning home to Vienna, undoubtedly in part because of the events of the war years [see Chapter 6], but also because he recognized the Vienna of which he felt himself part both personally and as a dramatist, no longer existed, as he made clear in the first version of "Über mein Theater", when modestly attributing his success to good fortune:

So war es eigentlich ein Negativum, der Mangel an echten Theaterstükken, das Ueberhandnehmen des kabarettistischen Dramas, das meinen Stücken in den letzten zehn Jahren die Chance gab, sich international durchzusetzen. Nicht weil sie hervorragend waren, sondern weil unter Blinden leicht der Einäugige König für einen Tag wird, wurden sie häufiger gespielt als sie es hinsichtlich ihrer objektiven Qualität verdienten. Vielleicht auch deshalb, weil sie im Guten und Schlechten in einer Volkstheater-Tradition verwurzelt sind, denn ein Weg in die Welt aus dem Bodenlosen dürfte unmöglich sein. Freilich, einäugig - ich bitte das festzuhalten. Das andere Auge ging früh verloren mit allem, was sonst verloren ging, und das ist leider, vom Theater aus betrachtet, sehr viel: die Hauptstadt, denn ohne Hauptstadt kein Drama; die allgemeine Produktivität, denn nur sie verbürgt das Hervorragende, das niemals mit dem Vereinzelten identisch ist, wie schon die Bezeichnung klar macht. Ohne Kameradie [sic]

1 Walter Zitzenbacher, "Porträt der Woche". In: Kleine Zeitung [Graz], 8. April 1967.

2 It became clear from personal experience in Europe in 1990-91 that while Hochwälder was a name recognized in Austria this was rarely the case in Germany or elsewhere.

3 Cf. Fritz Hochwälder, Im Wechsel der Zeit. Autobiographische Skizzen und Essays (Graz: Styria, 1980), 82-83. 
kann der Vereinsamte mit seinem Pfund nicht so wuchern wie er sollte und möchte, zumal auf dem Gebiet des Theaters, welches das Kollektiv, die Zusammenarbeit vieler nicht nur begünstigt, sondern fordert ${ }^{4}$.

There could be no return for the dramatist, despite his assertion: "Ich bin und bleibe Wiener"5, for the Vienna of his youth, so lovingly described in essays such as "Auf der Gassen..." was no more. As he observed in 1976: "Heimkehr nach dreieinhalb Dezennien, das ist Agamemnons Badezimmer"7. Although he maintained contact with his home city throughout his life, Hochwälder nevertheless remained a dramatist in voluntary exile.

Secondly, in addition to his geographical isolation, Hochwälder also set himself apart both stylistically and theoretically from mainstream post-war drama, maintaining a strictly conservative approach to drama in all but a few of his plays, which could be loosely described as "Aristotelian": the plot of a typical Hochwälder play unfolds in three or five acts, makes use of the three unities, and employs conventional devices such as exposition, peripeteia and denouement. His first major success, Das heilige Experiment. Schauspiel in fünf Aufzügen, serves as a good example.

Not only did this set Hochwälder apart from mainstream theatrical movements such as the Theatre of the Absurd, Existentialism, Documentary Theatre, and Brecht's Epic Theatre, but his own views on what constituted good theatre openly challenged the dramatic experiments of others. This is laid out most clearly in his essay "Vom Versagen des Dramas in unserer Zeit" he bemoans the decline of the popularity of the tragedy, taking issue with the views of Dürrenmatt ${ }^{9}$, and decries the loss of the three virtues at the heart of good drama: "Verlust der Sprache, Verlust des Gewissens, Verlust der Naivität" 10 . He also rejects Brecht's dramatic theories, while admiring his plays and poetry, responding to Brecht's dismissal of "Aristotelian Theatre" with: "Das kulinarische Theater ist eben doch was Schönes" ". Elsewhere his attacks on modern theatrical developments become vitriolic when he slates the experimentation of dramatists and Dramaturgen, particularly in the highly subsidized theatres of the Federal Republic of Germany ${ }^{12}$. It is not difficult to

${ }^{4}$ Fritz Hochwälder, "Über mein Theater", German Life and Letters, 12 (1959), 113.

5 Hochwälder, Im Wechsel der Zeit, 92.

${ }^{6}$ Hochwälder, Im Wechsel der Zeit, 13-25.

${ }^{7}$ Hochwälder, Im Wechsel der Zeit, 31.

8 Hochwälder, Im Wechsel der Zeit, 57-80.

9 Hochwälder, Im Wechsel der Zeit, 78. It should be noted Hochwälder admired Dürrenmatt's dramas.

10 Hochwälder, Im Wechsel der Zeit, 60.

11 Hochwälder, Im Wechsel der Zeit, 75; ref. 73-75.

12 Wolfgang Arnold, "Der Mann, der es schwer macht", Südost Tagespost [Graz], 20. Aug. 1970; Reinhard Noll, "Das Häuflein mafiosi in die Schranken weisen...", Mannheimer Morgen, 5. Juni 1973; Peter Vujica, "Fritz Hochwälder wörtlich", Neue Vorarlberger Tagesz- 
imagine that such antagonism would discourage any interest in him or his work from more innovative producers, as well as alienating critics, Germans in particular, who did not escape his wrath.

A final possible reason for why Hochwälder has largely been ignored by critics, particularly in recent years, is that his dramatic output sharply declined from the end of the $1950 \mathrm{~s}$. Of the nineteen published plays, eleven were written prior to 1960 , three appeared in the $1960 \mathrm{~s}^{13}$, while between 1968 and 1982 only Lazaretti oder Der Säbeltiger. Schauspiel in drei Akten appeared, to a very poor reception. His last three plays, Die Prinzessin von Chimay. Komödie in drei Akten, Der verschwundene Mond. Märchenspiel in zwei Akten (Dreizehn Szenen) and Die Bürgschaft. Eine antikisch verkleidete Satire in drei Akten in Dramen IV were not performed in his lifetime. His last published play, Holokaust (Totengericht). Schauspiel in drei Akten was published posthumously in 1998. Hochwälder's decline in productivity, no doubt in part due to age and ill-health ${ }^{14}$, coincided with the establishment of a new generation of Austrian playwrights in the 1960s and 1970s, such as Peter Handke, Wolfgang Bauer, and Thomas Bernhard. While the obituaries on his death in 1986 praised his contribution to the stage, he was to a largely a forgotten dramatist, honoured but rarely performed ${ }^{15}$.

Such considerations aside, Hochwälder played a significant role in not just Austrian but European post-war drama, and his neglect by scholarly research is a considerable oversight. To date there has been only one major study published on him, Wilhelm Bortenschlager's Der Dramatiker Fritz Hochwälder ${ }^{16}$, which, written in 1979 , does not cover the later published plays. It provides an overview of Hochwälder's output and biographical detail, and is one of the few works to include the unpublished dramas. However, it suffers from the weakness of substituting synopses for detailed analysis, and offers little insight to the main thematic concerns of Hochwälder's dramas.

The few theses on the Austrian playwright were also written during his lifetime, and can therefore not provide a complete retrospective picture of his work. The most recent of these is "Fritz Hochwälder as Heir to the Viennese Hanswurst Tradition with a Hochwälder Bibliography" by Elwood Venton Chandlee, Jr. ${ }^{17}$ As its starting point it uses Hochwälder oft-repeated insisten-

eitung [Bregenz], 29. Juli 1975; Thomas Dobernigg, "Fritz Hochwälder: 'Den Regieunholden muß man das Handwerk legen"', Kärntner Tageszeitung [Klagenfurt], 1. Aug. 1980, 7.

${ }^{13}$ This is treating the two versions of Der Befehl as one.

14 He suffered several heart-attacks in later life.

15 One critic observed that he had been honoured with the Franz Theodor Csokor Prize: "[...] den Preis eines Dramatikers, den man nicht spielt, für einen Dichter, den man nicht mehr spielt" (Kurt Wimmer, "Ich warte, bis ich ausgegraben werde", Kleine Zeitung [Graz], 29. Juni 1984, 3].

16 Wilhelm Bortenschlager, Der Dramatiker Fritz Hochwälder, (Innsbruck: Universitätsverlag Wagner, 1979).

17

Elwood Venton Chandlee $\mathbf{J}_{\mathbf{r}}$., "Fritz Hochwälder as Heir to the Viennese Hanswurst Tradition with a Hochwälder Bibliography", Diss., Univ. of Southern California, 1979. 
ce on being part of the Viennese Volkstheater tradition ${ }^{18}$ to explore the role of Hanswurst characters in Hochwälder's plays. Chandlee, however, clearly struggles from a lack of material, for with odd exceptions such as Escambarlat in Donadieu. Schauspiel in drei Akten and Birnstrudl in Donnerstag. Ein modernes Mysterienspiel, genuine Hanswurst figures do not appear in Hochwälder's dramas. This, no doubt, accounts for the fact that less than half of the thesis is directly concerned with Hochwälder's work and why there is an emphasis on the bibliography.

Maria Holdman's thesis, "The Concept of Order in the Drama of Fritz Hochwälder"19 (1976), has more to offer, although it limits its scope of interest to six selected plays: Der öffentliche Ankläger. Schauspiel in drei Akten; Der Unschuldige. Komödie in drei Akten; Der Himbeerpflücker. Komödie in drei Akten; both versions of Der Befehl ${ }^{20}$; and Das heilige Experiment. She explores the relationship between Befehl, directives and commands, and Ordnung, the ordered existence and structures, in the plays, observing how the lives of individual characters may be disrupted by directives from outside. James Schmitt in his 1973 thesis, "The Theme of Responsibility in the Drama of Fritz Hochwälder from 1943-1965"21, sets out to redress the lack of critical interest shown in the dramatist, and explores a theme closely related to that studied in this work. Yet, while he provides interesting background on the author, his study remains very limited in scope and provides very poor and brief analyses of the plays, devoting as little as three to four pages to works of the importance of Der öffentliche Ankläger, Donadieu and Der Unschuldige.

Mention should also be made of two Masters dissertations. Eileen Murphy's "The Drama of Fritz Hochwälder"22 (1972) provides a most useful overview of Hochwälder's work, and has the added strength of covering the unpublished dramas. It does occasionally lay too much emphasis on a supposed pacifist message in the plays, but generally contains much good material and competent analysis.

Thomas D. Haley's “A Translation and Analysis of Der Unschuldige (The Innocent Man) by Fritz Hochwälder" ${ }^{23}$ (1969) on the other hand, as the title

18 A claim made most notably in essays such as "Vom Versagen des Dramas in unserer Zeit" and "Über mein Theater".

19 Marie Paula Holdman, "The Concept of Order in the Drama of Fritz Hochwälder", Diss., City Univ. of New York, 1976.

20 Der Befehl. Fernsehspiel, 1967; Der Befehl. Schauspiel in drei Akten, 1968 [See Chapter 6].

21 James J. Schmitt, "The Theme of Responsibility in the Drama of Fritz Hochwälder from 1943-1965", Diss, Univ. of Iowa, 1973. This work also examines Der Befehl (1967), which Schmitt dates 1965. It has much in common with what is presumed to be an earlier work: James [J.] Schmitt, "Fritz Hochwälder's Dramas: 1943-1965", Masters [?] diss., Rockford College, undated.

22 Eileen Murphy, "The Drama of Fritz Hochwälder", Masters diss., Univ. College, Swansea [Wales], 1972. 
suggests, provides a very limited examination of the dramatist's work, and is of dubious academic worth.

Several relatively recent articles have provided general appraisals of Hochwälder's work and are worthy of mention. Donald G. Daviau has made the most substantial contribution in this respect, in three articles published in the $1980 \mathrm{~s}^{24}$ that provide a solid overview and explore themes such as the conflict between conscience and following orders, Hanswurst figures in the plays, and the conflict between good and evil within individuals. However, several interpretations of individual plays will be challenged in later chapters, and Daviau's assertion that Hochwälder moved from a demand for justice in the early dramas to an overriding concern for order, even at the expense of calling criminal behaviour to account, is highly questionable. The articles are also marred by sins of inaccuracy such as giving the wrong date for Hochwälder's death ${ }^{25}$, claiming Hochwälder was a Catholic, when in fact he was an agnostic ${ }^{26}$, and attributing fifteen published plays to Hochwälder, when, if one treats the two versions of Der Befehl as one play, there were, at the time of his writing, eighteen.

Another important contributor, particularly regarding the theme of conscience, is U. Henry Gerlach, whose article, "Das Motiv des unterdrückten Gewissens in den Dramen Fritz Hochwälders"27, widens the scope of his earlier essay, "Unterdrücktes Gewissen als Zentralmotiv in Fritz Hochwälders Heiligem Experiment" 28 , in exploring how characters deliberately ignore the voice of conscience.

Both Anthony Harper ${ }^{29}$ and Alan Best ${ }^{30}$ have also provided general surveys

${ }^{23}$ Thomas D. Haley, "A Translation and Analysis of Der Unschuldige (The Innocent Man) by Fritz Hochwälder", Masters diss, Univ. of Denver, 1969.

24 Literature. 18, 2 (1985), 31-45; Donald G. Daviau, "Fritz. Hochwälder", Major Figures of Modern Austrian Literature, ed. Daviau, (Riverside, California: Ariadne, 1988), 237-267; Donald G. Daviau, "Der innere Konflikt zwischen Gut und Böse in den Dramen von Fritz Hochwälder", Die österreichische Literatur: Ihr Profil von der Jahrhundertwende bis zur Gegenwart 1880-1990, Hrsg. Herbert Zeman, Bd. II. (Graz: Akademische Druck- u. Verlagsanstalt, 1989), 905-925.

25

26 avau, "Fritz Hochwalder", 237, "Der innere Konflikt zwischen Gut und Böse [...]", 906.

26 Daviau, "Fritz Hochwälder", 254. In correspondence Hochwälder referred to being a Jew of "profunde Glaubenslosigkeit" (Fritz Hochwälder, Brief an Ernst Waldinger, 14. Aug. 1965, Dokumentationsstelle für neuere österreichische Literatur, Wien). Cf. Im Wechsel der Zeit, 89; Brief an Ernst Waldinger, 22. Feb. 1966, Dokumentationsstelle für neuere österreichische Literatur, Wien.

27 U. Henry Gerlach, "Das Motiv des unterdrückten Gewissens in den Dramen Fritz Hochwälders", Modern Austrian Literature. 16, 1 (1983), 53-71.

28 U. Henry Gerlach, "Unterdrücktes Gewissen als Zentralmotiv in Fritz Hochwälders Heiligem Experiment", Österreich in Geschichte und Literatur. 24 (1980), 360-366.

29 Anthony J. Harper, "Tradition and Experiment in the Drama of Fritz Hochwälder", Time and Change. Essays on German and European Literature, by Harper, (Frankfurt/M: R.G. Fischer, 1982), 47-54.

30 Alan Best, "Shadows of the Past: The Drama of Fritz Hochwälder", Modern Austrian Writing. Literature and society after 1945, ed. Alan Best and Hans Wolfschütz, (London: 
of Hochwälder's work. The former takes issue with the categorization of the Austrian dramatist as simply a "traditionalist", while Best sees Hochwälder as fundamentally a pessimist who constantly demonstrates the break down of individual "Ordnung" and the destruction of the illusion of security, from which characters escape only by chance.

Sound, but by now somewhat dated introductions to the dramatist, are also provided by George Wellwarth ${ }^{31}$, who like Daviau makes much of the internal struggles facing Hochwälder's characters, and Gotthard Böhm ${ }^{32}$, who provides useful material on the reception of the playwright in his native Austria.

From this brief survey of the secondary literature, an extensive examination of Hochwälder's contribution to post-war drama is clearly long overdue, and the primary purpose of this study is to provide a detailed analysis of his entire dramatic ceuvre. In doing so a central theme throughout his work will be explored: the insistence on the need to accept personal responsibility for one's actions and to heed the voice of conscience, the quality that Hochwälder sees as distinctively human. This emphasis, which with justification has been seen as part of a humanistic tradition encompassing the philosophy of Kant and the central tenets of Schiller's work ${ }^{33}$, is made in the full recognition of the potential for wrongdoing in human nature, and the lengths to which individuals will go to avoid accepting the burden of responsibility. Hochwälder's personal suffering at the hands of the Nazis ensured he was well aware of the capacity for evil in every individual, which, given particular circumstances, may be allowed to come to the fore. Repeatedly it is shown in his dramas that one cannot know of what others, or indeed oneself, may be capable when put to the test. The only safeguard upon which one can rely when confronted by evil is the conscience.

Indeed, in many respects, as James Schmitt has indicated ${ }^{34}$, most of Hochwälder's works stand in the shadow of the experience of National Socialism. Although often dressed in historical garb they explore how human weakness can lead to evil, either through direct participation, or by failing to directly oppose it. These failings, which are ruthlessly exposed in Hochwälder's historical plays, are the same as those demonstrated in the dramas which directly confront the Nazi heritage. In recognising that a major contributor to the horror that was National Socialism was the wholesale failure to accept individual responsibility, Hochwälder also does not shirk from asking what such behaOswald Wolff, 1980), 44-62.

31 George Wellwarth, "Fritz Hochwälder. The Drama within the Self", The Theater of Protest and Paradox. Developments in the Avant-Garde Drama, by Wellwarth, Rev. ed. (New York: New York University Press, 1971), 207-221.

32 Gotthard Böhm, "Der geborene Dramatiker: Fritz Hochwälder", Die zeitgenössische Literatur Österreichs, Hrsg. Hilde Spiel, Bd. 3 von Kindlers Literaturgeschichte der Gegenwart, Autoren. Werke. Themen. Tendenzen seit 1945, (Zürich: Kindler, 1976), 534-547.

33 Cf. Edward R. McDonald, "The Classical Theater-of-Illusion Modernized - The Conflicting Messages of the Moral Imperative in Fritz Hochwälder's Drama Das heilige Experiment", Maske und Kothum. 31 (1985), 73-100.

${ }^{34}$ Schmitt, "The Theme of Responsibility [...]", 24-25. 
viour may mean for the future survival of humanity, and whether the humanistic values he holds so dear can survive.

Hochwälder's characters show a range of different motivation for ignoring the inner voice of conscience and behaving immorally. The most common is naked self-interest. Often, his plays are set in an environment that encourages such behaviour: societies which value material possessions, wealth and power above all else. Yet the folly of believing money and success may provide happiness is demonstrated by characters who have achieved this, but remain unsatisfied, and by those who pursue these ends only to be profoundly disappointed.

The necessity to flee evil in order to survive, may provide the excuse to abandon the struggle against it, once one is safe. But this position is also shown to be irresponsible, for failure to do so may contribute to inhumanity and crime, and may come back to haunt the guilty individual. Nor is it acceptable to protect oneself and abdicate personal responsibility by hiding behind orders or the authority of others, for this too contributes to evil and may ultimately destroy that which individual characters believe they are protecting. Perhaps the most understandable reason for moral failure in Hochwälder's work is the temptation to put too much faith in a higher order, be it religious, political or philosophical, as the only means of changing a cruel, inhuman world. But such idealism can quickly become corrupted once individuals are prepared to sacrifice their own critical faculties to the judgement of others, and then may lead to further inhumanity and the suffering not only of the guilty characters but innocent victims. There can never be any compromise with evil. Faced with moral dilemmas, Hochwälder's characters are shown again and again to be ultimately on their own. This isolation can be both physical and emotional, and nothing or no one may be able to help the individual choose what course of action to take. Indeed, such is the fundamental isolation of many characters from one another that they do not really know even those closest and dearest to them. That which may be hidden in a person's soul is not necessarily visible from the outside.

The human weaknesses exposed in Hochwälder's early plays, reappear in those that examine the lingering consequences of the National Socialist legacy in the 1960 s. Here, the failure to accept personal responsibility is combined with an attempt at Vergangenheitsbewältigung. Hochwälder recognizes how little the human race seems prepared to learn from its mistakes and how easily they may be repeated in the future.

Such a gloomy prospect leads to the inescapable question about the future of mankind. He raises the spectre of a voluntary sacrifice of the one attribute that distinguishes humanity: the Gewissen. Individuals who seem able to exist without any qualms or pangs of conscience are for Hochwälder Nichtmenschen; their behaviour is only restricted by the dictates of the current legal system. That such creatures are already amidst society would seem to be attested to by the Holocaust, in which seemingly normal people were capable of the most monstrous crimes, sanctioned by the state. This train of thought 
leads to a further disturbing question being raised: is the human race genetically flawed and doomed to extinction; a freak of nature soon to disappear from the face of the earth?

Yet for all the pessimism evident in Hochwälder's later works, an underlying optimism remains discernable. In the majority of his plays viable, ethical alternatives are presented and characters are able to lift themselves above the inhumanity around them. There exists in the dramas a tentative faith that justice can be done, that evil need not indefinitely triumph. It remains a question of conscience for the potential for both good and evil lies in each individual. The conquest of one or the other remains a matter of vital personal choice. 